\title{
The Relationship Between the VARK Learning Styles and Academic Achievement in Dental Students
}

This article was published in the following Dove Press journal:

Advances in Medical Education and Practice

\author{
Hamid Reza Mozaffari ${ }^{1}$ \\ Maryam Janatolmakan (iD ${ }^{2}$ \\ Roohollah Sharifi ${ }^{3}$ \\ Fatemeh Ghandinejad ${ }^{4}$ \\ Bahare Andayeshgar (iD ${ }^{5}$ \\ Alireza Khatony iD ${ }^{6}$ \\ 'Department of Oral and Maxillofacial \\ Medicine, School of Dentistry, \\ Kermanshah University of Medical \\ Sciences, Kermanshah, Iran; ${ }^{2}$ Medical \\ Surgical Nursing, Clinical Research \\ Development Center, Imam Reza \\ Hospital, Kermanshah University of \\ Medical Sciences, Kermanshah, Iran; \\ ${ }^{3}$ Department of Endodontic, School of \\ Dentistry, Kermanshah University of \\ Medical Sciences, Kermanshah, Iran; \\ ${ }^{4}$ Kermanshah University of Medical \\ Sciences, Kermanshah, Iran; ${ }^{5}$ Statistic, \\ Clinical Research Development Center, \\ Imam Reza Hospital, Kermanshah \\ University of Medical Sciences, \\ Kermanshah, Iran; ${ }^{6}$ Social Development \\ and Health Promotion Research Center, \\ Kermanshah University of Medical \\ Sciences, Kermanshah, Iran
}

Correspondence: Alireza Khatony Clinical Research Development Center, Imam Reza Hospital, Kermanshah, Iran $\mathrm{Tel} / \mathrm{Fax}+9883382793949$

Email akhatony@gmail.com

\begin{abstract}
Background: Learning style is a factor influencing academic achievement. There are contradictory results in studies on the relationship between learning styles and academic achievement. The current study aimed at investigating the relationship between learning styles and academic achievement in dental students.
\end{abstract}

Methods: In the current descriptive-analytical study, 184 dental students were selected by simple random sampling. The VARK questionnaire was used as the data collection tool. The grade point average (GPA) of previous semester was used as an indicator of academic achievement, and accordingly, students were divided into two groups of strong (GPA $\geq 15$ ) and weak (GPA $\leq 14.99$ ).

Results: The most common learning styles in strong students were unimodal ( $\mathrm{n}=55,42 \%)$ and bimodal $(\mathrm{n}=41,31.3 \%)$, while they were unimodal $(\mathrm{n}=28,47.2 \%)$ and bimodal $(\mathrm{n}=24$, $45.3 \%$ ) in the weak students. There was no significant relationship between learning styles and academic achievement in the two groups of strong and weak students.

Conclusion: No significant relationship was found between learning style and academic achievement. Further studies with larger sample sizes are recommended. Further studies with larger sample sizes are recommended.

Keywords: academic performance, dental, learning, model, students

\section{Introduction}

Academic achievement is one of the most important parameters used to predict the future academic status of learners. ${ }^{1}$ Learning styles are of the factors influencing academic achievement. ${ }^{2}$ The learning style is defined as a combination of cognitive, emotional, and physiological traits that show how the learner perceives and responds to the learning environment. ${ }^{3}$ Understanding learning style of learners can be effective in organizing and modifying the learning environment and teaching and learning process. ${ }^{4}$ Each student has his/her own learning style. ${ }^{5}$ There are several methods to measure learning styles and the VARK questionnaire developed by Fleming and Mills (1992) is the most widely used one. According to this questionnaire, learning styles comprises visual (V), aural (A), reading/writing $(\mathrm{R})$, and kinesthetic $(\mathrm{K})$ models. ${ }^{6}$ Visual learners learn through watching videos, images, and figures. Aural learners learn through listening to lectures; reading-writing learners through reading texts and writing notes on them, and kinesthetic learners through touch and manipulation of objects. 6,7 
According to the VARK model, one may apply multiple learning styles. ${ }^{4}$ Various studies investigated the relationship between learning styles and academic achievement in students of different disciplines. In some of these studies, a significant relationship was found between learning style and academic achievement, ${ }^{8-12}$ while in some others, no significant relationship reported. ${ }^{13,14}$ The current study was designed and conducted in light of the importance of knowledge of teachers about learners' learning styles, and contradictory results of different studies on the relationship between learning styles and academic achievement. The present study aimed at determining the relationship between type and number of learning styles based on the VARK model and academic achievement in dental students of Kermanshah University of Medical Sciences (KUMS).

\section{Materials and Methods Study Design}

The current cross-sectional, descriptive-analytical study was performed on dental students.

\section{Study Questions}

We sought to answer the following questions: 1) What is the academic status of dental students?, 2) What is the frequency of learning styles among dental students?, and 3) What is the relationship between academic achievement and learning style in dental students?

\section{Sample and Sampling Method}

The study population included dental students of KUMS. The Cochran formula was used to determine the sample size; with a confidence of $95 \%$, the sample size was 184 . Inclusion criteria were willingness to participate in the study and studying in third semester and higher. Simple random sampling was used in the current study.

\section{Measurement Instrument}

Data collection tools included a demographic information sheet and the VARK questionnaire. The demographic information sheet included four items on age, gender, marital status, and the grade point average (GPA) of the two latter semesters. The VARK questionnaire is a standard tool, ${ }^{15}$ which its validity and reliability were assessed and confirmed in a study by Zhu (2018). ${ }^{16}$ The Persian version of the VARK questionnaire was psychometrically assessed by Mehdipour et al, (2018) in Iran. ${ }^{17}$
The VARK questionnaire consists of 16 multiplechoice items and can be used to identify four types of learning styles. Each item is related to a particular style. The respondents should choose the options according to their preferences, and if one choice does not reflect the whole view, they can choose more options and leave items not happened yet. Higher scores in each learning style indicate the respondents' greater desire for that style. If an individual gets equal scores in two or more styles, his/ her learning style is considered "multimodal". Total score in each item ranges from zero to 16. The GPA of the last two semesters was used to determine academic status. The students were divided into two groups of strong (GPA $\geq 15)$ and weak $(\mathrm{GPA} \leq 14.99)$ based on their GPA.

\section{Data Collection}

First, the list of students studying in the third semester and above was taken from the Department of Education at the Faculty of Dentistry, and numbered. Then, using random number table, 184 students entered the study and the ones who agreed to participate, received a questionnaire.

\section{Data Analysis}

Data were analyzed by the SPSS v.18.0 software using descriptive and inferential statistics. First, the Kolmogorov-Smirnov test, showing abnormal distribution of GAP and learning style variables, was performed. ChiSquared test was also utilized to determine the relationship between academic achievement and learning styles. The significance level was considered less than 0.05 .

\section{Ethical Considerations}

The Ethics Committee of the University approved the study with the code: KUMS.REC.2017.627. Written informed consent was obtained from all students and they were assured of the confidentiality of their information.

\section{Results}

According to the obtained results, most subjects were female $(58.7 \%, \mathrm{n}=108)$ and single $(63 \%, \mathrm{n}=116)$. Their mean age was $24 \pm 30$ years. In the group of strong students, majority of the subjects were within the age range of 21-23 years, but in the weak students group, 24-27 years was the most frequent age group (41.5\%, $\mathrm{n}=22$ ) (Table 1).

Results showed that the majority of students $(n=131$, $71 \%$ ) were in the strong group. In addition, reading-writing 
Table I Demographic Characteristics of Study Subjects $(n=184)$

\begin{tabular}{|l|l|l|l|}
\hline \multicolumn{2}{|l|}{$\begin{array}{l}\text { Demographic } \\
\text { Variables }\end{array}$} & \multicolumn{2}{|l|}{ Groups } \\
\cline { 3 - 4 } & $\begin{array}{l}\text { Strong Students } \\
\text { Number (\%) }\end{array}$ & $\begin{array}{l}\text { Weak Students } \\
\text { Number (\%) }\end{array}$ \\
\hline Sex & $\begin{array}{l}\text { Female } \\
\text { Male }\end{array}$ & $\begin{array}{l}89(67.94) \\
42(32.06)\end{array}$ & $\begin{array}{l}19(35.85) \\
34(64.15)\end{array}$ \\
\hline Marital & Single & $93(50)$ & $23(12)$ \\
status & Married & $38(20)$ & $14(7)$ \\
\hline Age & $18-20$ & $8(6.2)$ & $5(9.46)$ \\
(year) & $21-23$ & $50(38.26)$ & $13(24.52)$ \\
& $24-27$ & $46(35.21)$ & $22(41.5)$ \\
$10(18.86)$ \\
\end{tabular}

$(\mathrm{n}=87.66 .4 \%)$ and kinesthetic $(\mathrm{n}=22,16.8 \%)$ were the most and least frequent learning styles, respectively, in the strong group. Also, in the weak students group, the reading-writing and kinesthetic learning styles had the highest $(\mathrm{n}=30$, $56.6 \%)$ and lowest $(n=7,13.2 \%)$ frequencies, respectively. Regarding the learning style used, no significant difference was found between strong and weak students (Table 2). In terms of the number of learning styles used by the strong students, the results showed that $42 \%(n=55)$ of the subjects were unimodal and about one-third bimodal $(n=41,31.3 \%)$. In the weak students group, the majority of subjects were unimodal $(\mathrm{n}=28,47.2 \%)$ and bimodal $(\mathrm{n}=24,45.3 \%)$.
There was no significant difference in the number of learning styles used between the strong and weak student groups (Table 3).

\section{Discussion}

The current cross-sectional study aimed at determining the relationship between the type of learning style used and academic achievement in dental students. Findings showed that reading/writing style had the highest frequency in both groups of strong and weak students. In a study (2016) on the learning style of dental students in Saudi Arabia, kinesthetic (35.1\%) and aura (35.1\%) were the most common learning styles used. ${ }^{6}$ Results of a study (2018) in Saudi Arabia on dental students showed that the most commonly used learning styles were aural and kinesthetic. ${ }^{18}$ In a study in the USA on anatomy students (2018), the most common learning style was kinesthetic. ${ }^{19}$ The results of the study by Habibpour et al (2016), in Iran on medical students showed that the most common learning style used was reading-writing. The results of the aforementioned studies show that students have various learning styles. The predominance of some particular learning styles in students can be related to their field of study, teaching methods, learning experiences, curriculum content, and volume of course content. Therefore, it is suggested that teachers pay more attention to the

Table 2 Relationship Between Types of Learning Styles and Academic Achievement in Study Subjects

\begin{tabular}{|l|l|l|l|l|l|}
\hline \multirow{2}{*}{ Groups } & \multicolumn{2}{|l|}{ Learning Styles } & $\begin{array}{l}\text { Test } \\
\text { Result }\end{array}$ \\
\cline { 2 - 6 } & $\begin{array}{l}\text { Visual Number } \\
(\%)\end{array}$ & $\begin{array}{l}\text { Audible } \\
\text { Number (\%) }\end{array}$ & $\begin{array}{l}\text { Readable - Write } \\
\text { Number (\%) }\end{array}$ & $\begin{array}{l}\text { Motion-Movement } \\
\text { Number (\%) }\end{array}$ \\
\hline $\begin{array}{l}\text { Strong students (GPA* } \\
\geq 15)\end{array}$ & $41(31.3)$ & $56(42.7)$ & $87(66.42)$ & $22(16.8)$ & $\begin{array}{l}\chi^{2}=1.052 \\
\text { NS** }\end{array}$ \\
\hline $\begin{array}{l}\text { Weak students (GPA } \\
\leq 14.99)\end{array}$ & $18(33.4)$ & $25(47.2)$ & $30(56.6)$ & $7(13.2)$ & \\
\hline
\end{tabular}

Notes: *Grade Point Average. **Non-significant.

Table 3 Relationship Between Number of Learning Styles and Academic Achievement Among Study Subjects

\begin{tabular}{|l|l|l|l|l|l|}
\hline \multirow{2}{*}{ Groups } & \multicolumn{2}{|l|}{ Number of Learning Styles } & Test Result \\
\cline { 2 - 6 } & $\begin{array}{l}\text { Unimodal } \\
\text { Number (\%) }\end{array}$ & $\begin{array}{l}\text { Bimodal } \\
\text { Number (\%) }\end{array}$ & $\begin{array}{l}\text { Trimodal } \\
\text { Number (\%) }\end{array}$ & $\begin{array}{l}\text { Quadmodal } \\
\text { Number (\%) }\end{array}$ \\
\hline Strong students (GPA* $\geq 15)$ & $55(42)$ & $41(31.3)$ & $28(21.4)$ & $20(15.3)$ & $\chi^{2}=7.685$ \\
\hline Weak students (GPA $\leq 14.99)$ & $28(47.2)$ & $24(45.3)$ & $6(11.3)$ & $3(5.7)$ & \\
\hline
\end{tabular}

Notes: *Grade Point Average. **Non-significant. 
differences in learning styles among students when preparing the lesson plan.

In the current study, $42 \%$ of strong students and $47.2 \%$ of their weak peers were unimodal and in fact had a predominant learning style. The result was similar to those of the study by Zamani and Kaboodi (2017) on Iranian students, and Siddiqi et al (2012) and Haq et al (2012) in Pakistan. ${ }^{3}$ But in studies by Moshabab (2016) and Al-Saud (2013) in Saudi Arabia, Murphy et al (2004) in the USA, and Tantawi (2009) in Egypt, the predominant learning style of most dental students was multimodal, ${ }^{6,20-22}$ which is not in line with the result of the current study. The reasons for inconsistency between the results of the current study and the aforementioned studies may be differences in personal characteristics of the studied subjects and the teaching method of lecturers in the colleges.

The results showed no significant relationship between learning style and academic achievement. Almigbal et al (2015) in Saudi Arabia, Dobson et al (2010) and Dobson et al (2009) in the USA (2014), Urva et al in India (2014), and Mlambo et al (2011) in Jamaica also did not find a significant relationship between learning style and academic achievement, ${ }^{13,23-26}$ but Samarakoon et al (2013) in Sri Lanka, and Habibpour et al (2016) and Panahi et al (2012) in Iran reported a significant relationship between learning style and academic achievement in students. ${ }^{27-29}$ The relationship between learning style and academic achievement may vary in different situations. Choosing a teaching method based on the students' learning style can increase the students' interest in lessons and encourage their participation in the classroom, which can influence their academic achievement.

The present study also had some limitations. Since the current study had a cross-sectional design, it was not possible to investigate the likelihood of a cause-and-effect relationship between learning style and academic achievement. The selfreport method used to collect data in the current study might affect the accuracy of the results. The individuality of learning style used can also influence the generalizability of the results. Since students from third vs last grade may present differences due to acquired experience and maturity, the results might be affected when comparing students from different grades.

\section{Conclusion}

The most common learning style in strong and weak students was the reading-writing model. Most of the strong and weak students were unimodal and, in fact, had the same learning style preferences. No significant relationship was found between type and number of learning styles and academic achievement. Further studies with larger sample sizes are recommended in other dental schools.

\section{Acknowledgments}

This article was drawn from a research project (No 95563) sponsored by deputy of research and technology of Kermanshah University of Medical Sciences. We would like to express our sincere gratitude to all the students who participated in this research. We highly appreciate the Clinical Research Development Center of Imam Reza Hospital for their wise advices.

\section{Funding}

This study was drawn from a research project (No 95563) sponsored by deputy of research and technology of Kermanshah University of Medical Sciences.

\section{Disclosure}

The authors report no conflicts of interest in this work.

\section{References}

1. Dryer R, Henning MA, Tyson GA, Shaw R. Academic achievement performance of university students with disability: exploring the influence of non-academic factors. Intl $J$ Disabil Dev Educ. 2016;63(4):419-430. doi:10.1080/1034912X.2015.1130217

2. Özyurt Ö, Özyurt H. Learning style based individualized adaptive e-learning environments: content analysis of the articles published from 2005 to 2014. Comput Human Behav. 2015;52:349-358. doi:10.1016/j.chb.2015.06.020

3. Zamani N, Kaboodi A. Evaluation of the VARK model learning styles selection in medical students. Hrjbaq. 2017;2(2):109-115. doi:10.18869/acadpub.hrjbaq.2.2.109

4. Ahmadi M, Allami A. Comparison of health workers learning styles based on vark and kolbs' questionnaires and their relationship with educational achievement. Res Med Educ. 2014;6(1):19-28. doi:10.18869/acadpub.rme.6.1.19

5. Stirling BV, Alquraini WA. Using VARK to assess Saudi nursing students' learning style preferences: do they differ from other health professionals? J Taibah Univ Med Sci. 2017;12(2):125-130. doi:10.1016/j.jtumed.2016.10.011

6. Asiry MA. Learning styles of dental students. Saudi J Dent Res. 2016;7(1):13-17. doi:10.1016/j.sjdr.2015.02.002

7. Othman N, Amiruddin MH. Different perspectives of learning styles from VARK model. Procedia Soc Behav Sci. 2010;7:652-660. doi:10.1016/j.sbspro.2010.10.088

8. Farajollahi M, Najafi H, Nosrati Hashi K, Najafiyan S. Relationship between learning styles and academic achievement of university students. Sci j Educ Strategies Med Sci. 2013;6(2):83-88.

9. Rashidi Z, Moghadami M. The relationship between learning styles with academic achievement and creativity of students senior department of education, psychology and social sciences, Islamic Azad University Roudehen Branch. Innovation Creativity Human Sci. 2017;7(2):1-38.

10. Komarraju M, Karau SJ, Schmeck RR, Avdic A. The big five personality traits, learning styles, and academic achievement. Pers Individ. 2011;51(4):472-477. doi:10.1016/j.paid.2011.04.019 
11. Ruffing S, Wach F, Spinath FM, Brünken R, Karbach J. Learning strategies and general cognitive ability as predictors of gender-specific academic achievement. Front Psychol. 2015;6:1238. doi:10.3389/fpsyg.2015.01238

12. Li Y-S, Yu W-P, Liu C-F, Shieh S-H, Yang B-H. An exploratory study of the relationship between learning styles and academic performance among students in different nursing programs. Contemp Nurse. 2014;48(2):229-239. doi:10.1080/10376178.2014.11081945

13. Almigbal TH. Relationship between the learning style preferences of medical students and academic achievement. Saudi Med J. 2015;36 (3):349. doi:10.15537/smj.2015.3.10320

14. Liew S-C, Sidhu J, Barua A. The relationship between learning preferences (styles and approaches) and learning outcomes among pre-clinical undergraduate medical students. BMC Med Educ. 2015;15(1):44. doi:10.1186/s12909-015-0327-0

15. Fleming ND, Mills C. Helping students understand how they learn. Teach Professor. 1992;7(4):44-63.

16. Zhu H-R, Zeng $\mathrm{H}$, Zhang $\mathrm{H}$, et al. The preferred learning styles utilizing VARK among nursing students with bachelor degrees and associate degrees in China. Acta Paul Enferm. 2018;31(2):162-169. doi:10.1590/1982-0194201800024

17. Mehdipour M, Mortazavi H, Yazdani J, Namdari M, Moradi M. Learning styles of dental students at Shahid Beheshti University of Medical Sciences using VARK questionnaire. Iran J Med Educ. 2018;18:176-182.

18. Aldosari MA, Aljabaa AH, Al-Sehaibany FS, Albarakati SF. Learning style preferences of dental students at a single institution in Riyadh, Saudi Arabia, evaluated using the VARK questionnaire. Adv Med Educ Pract. 2018;9:179-186. doi:10.2147/AMEP.S157686

19. Husmann PR, O'Loughlin VD. Another nail in the coffin for learning styles? Disparities among undergraduate anatomy students' study strategies, class performance, and reported VARK learning styles. Anat Sci Educ. 2019;12(1):6-19. doi:10.1002/ase.1777

20. Al-Saud LM. Learning style preferences of first-year dental students at King Saud University in Riyadh, Saudi Arabia: influence of gender and GPA. J Dent Educ. 2013;77(10):1371-1378.
21. El Tantawi MM. Factors affecting postgraduate dental students' performance in a biostatistics and research design course. J Dent Educ. 2009;73(5):614-623.

22. Murphy RJ, Gray SA, Straja SR, Bogert MC. Student learning preferences and teaching implications. $J$ Dent Educ. 2004;68 (8):859-866.

23. Urval RP, Kamath A, Ullal S, Shenoy AK, Shenoy N, Udupa LA. Assessment of learning styles of undergraduate medical students using the VARK questionnaire and the influence of sex and academic performance. Adv Physiol Educ. 2014;38(3):216-220. doi:10.1152/ advan.00024.2014

24. Dobson JL. A comparison between learning style preferences and sex, status, and course performance. Adv Physiol Educ. 2010;34 (4):197-204. doi:10.1152/advan.00078.2010

25. Dobson JL. Learning style preferences and course performance in an undergraduate physiology class. Adv Physiol Educ. 2009;33 (4):308-314. doi:10.1152/advan.00048.2009

26. Mlambo V. An analysis of some factors affecting student academic performance in an introductory biochemistry course at the University of the West Indies. Caribbean Teach Scholar. 2011;1(2).

27. Habibpour Sedani S, Faeedfar Z, Abdeli Sultan Ahmadi J. A study on the learning styles of the students of Urmia University of Medical Sciences based on "vark" developing critical thinking, liveliness and achievement motivation. J Urmia Nurs Midwifery Fac. 2016;13 (12):1089-1096.

28. Samarakoon L, Fernando T, Rodrigo C, Rajapakse S. Learning styles and approaches to learning among medical undergraduates and postgraduates. BMC Med Educ. 2013;13(1):42. doi:10.1186/14726920-13-42

29. Panahi R, Kazemi S, Rezaei A. The relationship of learning styles to academic achievement: the role of gender and academic discipline. J Iran Psychol. 2012;8(30):189-196.
Advances in Medical Education and Practice

\section{Publish your work in this journal}

Advances in Medical Education and Practice is an international, peerreviewed, open access journal that aims to present and publish research on Medical Education covering medical, dental, nursing and allied health care professional education. The journal covers undergraduate education, postgraduate training and continuing medical education

\section{Dovepress}

including emerging trends and innovative models linking education, research, and health care services. The manuscript management system is completely online and includes a very quick and fair peer-review system. Visit http://www.dovepress.com/testimonials.php to read real quotes from published authors. 